\title{
NOTES
}

\section{Genus Hyphomonas Pongratz 1957 nom. rev. emend., Hyphomonas polymorpha Pongratz 1957 nom. rev. emend., and Hyphomonas neptunium (Leifson 1964) comb. nov. emend. (Hyphomicrobium neptunium)}

\author{
R. L. MOORE, ${ }^{1}$ R. M. WEINER, ${ }^{2 *}$ AND R. GEBERS ${ }^{3}$ \\ Department of Microbiology and Infectious Diseases, Faculty of Medicine, University of Calgary, Calgary, Alberta, \\ Canada T2N 4N1 ${ }^{1}$; Department of Microbiology, University of Maryland, College Park, Maryland 20742 ${ }^{2}$; and Institut für \\ Allgemeine Mikrobiologie, Universität Kiel, D-2300 Kiel, West Germany ${ }^{3}$
}

\begin{abstract}
We present evidence in support of revival of the genus Hyphomonas Pongratz 1957 and emend the description of this genus. The type species is Hyphomonas polymorpha nom. rev., with type strain PS728 (= ATCC $33881=$ IFAM PS728). A second strain of Hyphomonas polymorpha, strain PR727 (= ATCC 33880 = IFAM PR727), is also recognized. Transfer of a related organism, Hyphomicrobium neptunium strain LE670 (= ATCC 15444 = IFAM LE670), to the genus Hyphomonas is formally proposed.
\end{abstract}

In 1957, Pongratz reported the isolation of a prosthecate, budding bacterium from the nasal mucous of a patient with purulent sinusitis (14). A new genus was proposed to accommodate this organism, and the organism was named Hyphomonas polymorpha (14). This species was described in Bergey's Manual of Determinative Bacteriology, 8th ed. (1), but was not placed on the Approved List of Bacterial Names (16).

Pongratz (14) proposed a new genus because, unlike members of the genus Hyphomicrobium Stutzer and Hartleb 1898 (17), this organism grew on complex media, such as blood agar, and was unable to grow on simple mineral salts media containing only one-carbon compounds as the sole sources of carbon and energy. It also did not seem appropriate to place this non-photosynthetic bacterium with the photosynthetic members of the genus Rhodomicrobium Duchow and Douglas 1949 (2). The more recently described genus Pedomicrobium Aristovskaya 1961 emend. Gebers 1981 (3) is also unable to accommodate this organism since the members of this genus have the ability to produce heavy deposits of iron or manganese salts when they are grown in media containing fulvic acid-iron or -manganese sesquioxide complexes and they can be grown in media containing various organic acids or alcohols as carbon sources. The differential characteristics of these four genera are summarized in Table 1.

Deoxyribonucleic acid (DNA) homology studies have shown that Hyphomonas polymorpha has little or no genetic relatedness to representative strains of Hyphomicrobium, Rhodomicrobium, and Pedomicrobium (12; unpublished data). The results of ribosomal ribonucleic acid-DNA homology studies indicate that these genera are more closely related to one another than to other genera, but also support the validity of these taxa as separate genera (11). Several new isolates of prosthecate, budding bacteria which have recently been investigated demonstrate a closer morphological and nutritional resemblance to Hyphomonas polymorpha than to strains of other genera, and a significant degree of

* Corresponding author. relatedness has been observed between these strains and Hyphomonas polymorpha in DNA homology studies (unpublished data). It is likely that additional strains fitting the description of the genus Hyphomonas will be isolated in the future.

On the basis of these observations and the recommendations of Hirsch (5) and Moore (9), revival of the genus Hyphomonas and the type species Hyphomonas polymorpha is indicated.

Hyphomicrobium neptunium Leifson 1964 (7; strain LE670 [ = ATCC 15444 = IFAM LE670]) appears on the Approved Lists of Bacterial Names (16), although it was previously listed (5) as species incerta sedis and its transfer to the genus Hyphomonas had been proposed (5). This bacterium resembles Hyphomonas polymorpha morphologically, and, like Hyphomonas polymorpha, it requires certain amino acids for growth (4). However, serological relationships between these organisms were not observed (15). In DNA homology studies, Hyphomicrobium neptunium ATCC 15444 demonstrated $28 \%$ relatedness to Hyphomonas polymorpha ATCC 33881 but little or no relatedness to 20 strains of Hyphomicrobium, Rhodomicrobium vannielii, $\mathrm{Pe}$ domicrobium ferrugineum, three strains of Prosthecomicrobium, Ancalomicrobium adetum, and Caulobacter crescentus (12, 13; unpublished data). Differences between Hyphomicrobium neptunium and Hyphomicrobium sp. strain B522 in cell wall composition and susceptibility to sodium dodecyl sulfate have been reported (6). Similar comparisons between Hyphomicrobium neptunium and $\mathrm{Hy}$ phomonas polymorpha have not been made, but the relative ease of lysing either of these strains with sodium dodecyl sulfate compared with strains of Hyphomicrobium has frequently been observed (unpublished data). These results support the contention that Hyphomicrobium neptunium should be transferred to the genus Hyphomonas.

The following emended description is formally proposed for the genus Hyphomonas.

Description of the genus Hyphomonas Pongratz 1957 nom. rev. emend. Hyphomonas (Hy.pho.mo'nas. Gr. n. hyphos filament; M.L. n. monas small motile organism; M.L. fem.n. 
TABLE 1. Differential characteristics of the genera of bacteria which reproduce by budding from the tips of hyphae

\begin{tabular}{|c|c|c|c|c|}
\hline Characteristic & Hyphomonas ${ }^{a}$ & Hyphomicrobium ${ }^{a}$ & Pedomicrobium $^{a}$ & Rhodomicrobium ${ }^{b}$ \\
\hline Photosynthetic & - & - & - & + \\
\hline Able to use $C_{1}$ compounds as sole sources of carbon & - & + & - & - \\
\hline Requires amino acids as a source of carbon & + & - & - & - \\
\hline $\begin{array}{l}\text { Able to use a variety of organic acids and alcohols as sources } \\
\text { of carbon }\end{array}$ & - & - & + & + \\
\hline Produces cysts & - & - & - & + \\
\hline $\begin{array}{l}\text { Capable of depositing a heavy layer of iron or manganese } \\
\text { salts on the cell surface }\end{array}$ & - & - & + & - \\
\hline Main cell body retains its size and shape during the cell cycle & - & + & + & + \\
\hline No. of hyphae & $\begin{array}{l}1 \text { (occasionally } \\
2, \text { polar) }\end{array}$ & $\begin{array}{l}1 \text { (occasionally } \\
2, \text { polar) }\end{array}$ & $1-5$ & 2, polar \\
\hline
\end{tabular}

${ }^{a}$ Listed under budding and/or appendaged bacteria in Bergey's Manual, 8th ed. (1).

${ }^{b}$ Listed under the phototrophic bacteria (family Rhodospirillaceae) in Bergey's Manual, 8th ed. (1).

Hyphomonas hypha-bearing monad) strains are gram-negative, aerobic, heterotrophic, nonsporeforming, prosthecate, and budding. Young daughter cells are oval to pear shaped, smaller than the main body of the mother cell, and motile by means of a polar to lateral flagellum. Branching of the hyphae is rare during normal growth. Reproduction normally occurs by budding from the tip of the hypha, although bud formation directly from the mother cell may occur infrequently. Detailed investigations on the cell cycle have been described previously $(10,18)$.

All strains investigated thus far are catalase positive, peroxidase positive, coagulase negative, non-proteolytic, non-saccharolytic, nonpathogenic, and not acid-fast. Rapid lysis takes place in saline ethylenediaminetetraacetate supplemented with $1 \%$ sodium dodecyl sulfate. The cells contain both poly- $\beta$-hydroxybutyrate and polyphosphate.

Good growth occurs on Casamino Acids, blood agar, and other rich media; the addition of sea salts is required by some strains and is stimulatory to others (4). Growth in a defined medium supplemented with a mixture of glutamic acid, aspartic acid, methionine, and serine as substrates and with or without added growth factors (depending on strain), has been reported (4). Some strains exhibit brown pigmentation and alpha-hemolysis on salt-supplemented sheep blood agar. The optimum temperature for growth ranges from 22 to $42^{\circ} \mathrm{C}$; the optimum $\mathrm{pH}$ ranges from 7.0 to 8.6 .

The type species is Hyphomonas polymorpha Pongratz 1957, 607 nom. rev., with type strain PR728 (= ATCC 33881 = IFAM PR728) (po.ly.mor'pha. Gr. adj. poly many; Gr. N. morphe shape, body; M.L. adj. polymorpha many shapes). The base composition of the DNA of this smooth strain is 60 mol\% guanine plus cytosine, and that of the rough strain variant is $61 \mathrm{~mol} \%$ guanine plus cytosine (8). A description of this species has been given by Pongratz (14).

Hyphomonas cells are 0.5 to $1.0 \mu \mathrm{m}$ in diameter, approximately 1.0 to $3.0 \mu \mathrm{m}$ long, prolate, and spheroid. The narrow pole grows a tubelike extension (prostheca or hypha) about 0.2 to $0.3 \mu \mathrm{m}$ wide, which is commonly one to five times the length of the main cell body. Older cultures often contain abnormal cell types, including giant cells, spindles, and triangular forms, occasionally with more than one prostheca.

Young cells and hyphae have dense, homogeneous cytoplasm; abnormal forms, often with granules, have been observed.

Multiplication occurs by fission of mother and daughter cells. Slide cultures on nutrient agar at $20^{\circ} \mathrm{C}$ show the development of distal terminal knobs on the hyphae. In 1 to 2 $\mathrm{h}$ a bud (daughter cell) is completed and separates from the stalked mother cell. The bud becomes motile shortly after separation ("swarmer cell"), and the mother cell stalk elongates slightly before growing the next bud. Intercalary buds, interconnected by short hyphae, have been found occasionally.

Motility is due to a single, subpolarly inserted flagellum which can be retained after the development of a stalk and new daughter cell.

Staining is gram negative and not acid-fast. No endospores. Cells stain well with anilin dyes, neutral red, gentian violet, etc. The use of Lugol iodine as a mordant facilitates the staining of the narrow hyphae. Best results are obtained with silver impregnation. Upon isolation on solid media, colonies appear as smooth or rough types. The smooth colonies are round, convex, watery, and translucent and can be emulsified easily. The smooth organisms carry heavy capsules on the mother cells but usually not on the hyphae or buds. Rough colonies are rare; they are smaller and dry, forming a central crater after several days. The organisms cannot be readily emulsified, and suspensions thus remain granular. They lack capsules and are nonmotile. Smooth forms are stable variants, and rough forms split into both smooth and rough derivatives. The often voluminous capsules of the smooth organisms are readily stainable with Ziehl-Neelsen hot carbol-fuchsin.

Growth in broth is characterized by a fragile pellicle or granular turbidity or both.

Aerobic; catalase and peroxidase positive. Heterotrophic. Not proteolytic, hemolytic, or saccharolytic. Gelatin is not digested, and plasma is not coagulated. Pigments are not formed on complex media.

Optimum temperature, $37^{\circ} \mathrm{C}$. Growth is slow at 18 to $20^{\circ} \mathrm{C}$ and better at $30^{\circ} \mathrm{C}$. The optimum $\mathrm{pH}$ is 7.0 to 7.4 ; the $\mathrm{pH}$ range for growth is 6.5 to 8.5 . Poor or no growth on acid media commonly used for cultivation of fungi.

Growth is not influenced by light.

No growth on poor media, such as tap water supplemented with $\mathrm{KNO}_{3}$ and phosphate. Does not grow on mineral salts media which contain $\mathrm{CaCO}_{3}$, formate, acetate, propionate, lactate, methanol, ethanol, glycerol, or glycine as the sole source of carbon.

Does not attack arabinose, rhamnose, xylose, glucose, fructose, galactose, lactose, saccharose, maltose, trehalose, melibiose, raffinose, amidon, inulin, dextrin, glycogen, esculin, glycerol, erythritol, mannitol, sorbitol, or urea.

Good growth in coagulated serum, gelatin, blood agar, Loewenstein-Jensen medium, Dorset agar, and other rich media.

Reduces nitrate, nitrite, neutral red, methylene blue, and Janus green. Produces $\mathrm{H}_{2} \mathrm{~S}$. Indole is formed from trypto- 
phane. $\mathrm{NH}_{3}$ is produced, and the growth medium turns alkaline.

Resistant to penicillin ( $2 \mathrm{U})$, bacitracin ( $2 \mathrm{U})$, and furadoine $(10 \mu \mathrm{g})$. Very susceptible to chloramphenicol $(30 \mu \mathrm{g})$, streptomycin $(50 \mu \mathrm{g})$, neomycin $(30 \mu \mathrm{g})$, and sulfadiazine (1 $\mathrm{mg})$. Susceptible to tetracycline $(30 \mu \mathrm{g})$ and erythromycin $(15 \mu \mathrm{g})$.

Not virulent for mice $(5 \mathrm{ml})$, rats $(1 \mathrm{ml})$, guinea pigs $(1 \mathrm{ml})$ or rabbits $(1 \mathrm{ml})$ if a suspension which contains $5 \times 10^{9}$ cells per $\mathrm{ml}$ is injected subcutaneously or intraperitoneally. The organisms cannot be recovered from treated animals.

Pure cultures survive at room temperature or in a refrigerator for several months if they are suspended in peptone or nutrient broth.

Isolated only once from nasal mucous from a patient with infectious sinusitis.

Hyphomonas neptunium. The following description of $\mathrm{Hy}$ phomonas neptunium Leifson 1964, 249 nom. rev. (ex. Hyphomicrobium neptunium) strain LE670 (= ATCC 15444 = IFAM LE670) (nep.tu'.ni.um. Lat. n. Neptunus god of the sea) is based upon the descriptions of Leifson (7) and Hirsch (5).

Cells round to oval, ca. $1 \mu \mathrm{m}$ in diameter, usually with one hypha up to three times the length of the mother cell. Buds are oval with one to two polar or lateral flagella; buds motile until the hyphae form. Gram negative. Not acid-fast. No endospores.

On agar, the colonies are colorless; later they are tan, raised, semitranslucent or opaque, and, after 3 days, up to $1.5 \mathrm{~mm}$ in diameter.

In liquid media, growth is in the form of uniform turbidity without pellicle or sediment.

The best growth occurs in media containing sea salts. Does not grow on the mineral salts medium used for Hyphomicrobium vulgare.

Good growth in vitamin-free Casamino Acids containing $\mathrm{Mg}^{2+}$ or $\mathrm{Ca}^{2+}$ or seawater. Grows well in $0.2 \%$ Casitone containing $0.1 \%$ yeast extract and $0.3 \% \mathrm{MgCl}_{2}$. Vitamins are not required. Grows on a medium containing aspartate, glutamate, serine, and methionine plus marine salts (4).

Acid is not formed from glucose, sucrose, lactose, xylose, maltose, or mannitol. Gelatin, starch, and cellulose are not hydrolyzed. Lysine is deaminated; phenylalanine may be deaminated. Nitrate is reduced to nitrite. Catalase positive.

Temperature range, 4 to $40^{\circ} \mathrm{C}$; optimum temperature, 30 to $37^{\circ} \mathrm{C}$. $\mathrm{pH}$ range, 6.0 to 9.5 ; optimum $\mathrm{pH}$, ca. 8 .

Carbon dioxide is the primary end product of metabolism detected (4); however, the medium becomes alkaline during growth, probably due to the evolution of ammonia $(4,7)$. Deamination and tricarboxylic acid cycle oxidation of amino acids is a catabolic pathway (4). The DNA base content is 61 mol\% guanine plus cytosine (8). As determined by DNA base sequence homology, Hyphomonas neptunium is related to two strains of Hyphomonas polymorpha (counts 28 to $40 \%$ above background levels) but not to 20 Hyphomicrobium isolates (13).
Originally isolated from seawater that had been stored for 18 months and frozen for 2 days.

\section{LITERATURE CITED}

1. Buchanan, R. E., and N. E. Gibbons (ed.). 1974. Bergey's manual of determinative bacteriology, 8th ed. The Williams \& Wilkins Co., Baltimore.

2. Duchow, E., and H. C. Douglas. 1949. Rhodomicrobium vannielli, a new photoheterotrophic bacterium. J. Bacteriol. 58:409-416.

3. Gebers, R. 1981. Enrichment, isolation, and emended descriptions of Pedomicrobium ferrugineum Aristovaskya and Pedomicrobium manganicum Aristovskaya. Int. J. Syst. Bacteriol. 31:302-316.

4. Havenner, J. A., B. A. McCardell, and R. M. Weiner. 1979. Development of a defined minimal and complete medium for the growth of Hyphomicrobium neptunium. Appl. Environ. Microbiol. 38:18-23.

5. Hirsch, P. 1974. Genus Hyphomicrobium Stutzer and Hartleb 1898, p. 148-150. In R. E. Buchanan and N. E. Gibbons (ed.), Bergey's manual of determinative bacteriology, 8th ed. The Williams \& Wilkins Co., Baltimore.

6. Jones, H. E., and P. Hirsch. 1968. Cell-wall composition of Hyphomicrobium species. J. Bacteriol. 96:1037-1041.

7. Leifson, E. 1964. Hyphomicrobium neptunium sp. n. Antonie van Leeuwenhoek J. Microbiol. Serol. 30:249-256.

8. Mandel, M., P. Hirsch, and S. F. Conti. 1972. Deoxyribonucleic acid base compositions of hyphomicrobia. Arch. Mikrobiol. 81:289-294.

9. Moore, R. L. 1981. The genera Hyphomicrobium, Pedomicrobium, and Hyphomonas, p. 480-487. In M. P. Starr, H. Stolp, H. G. Trüper, A. Balows, and H. G. Schlegel (ed.), The prokaryotes. Springer-Verlag, New York.

10. Moore, R. L. 1981. The biology of Hyphomicrobium and other prosthecate, budding bacteria. Annu. Rev. Microbiol. 35:567594.

11. Moore, R. L. 1977. Ribosomal ribonucleic acid cistron homologies among Hyphomicrobium and various other bacteria. Can. J. Microbiol. 23:478-481.

12. Moore, R. L., and P. Hirsch. 1972. Deoxyribonucleic acid base sequence homologies of some budding and prosthecate bacteria. J. Bacteriol. 110:256-261.

13. Moore, R. L., and J. T. Staley. 1976. Deoxyribonucleic acid homology of Prosthecomicrobium and Ancalomicrobium strains. Int. J. Syst. Bacteriol. 26:283-285.

14. Pongratz, E. 1957. D'une bactérie pédiculee isolée d'un pus de sinus. Schweiz. Z. Allg. Pathol. Bakteriol. 20:593-608.

15. Powell, D. M., B. S. Roberson, and R. M. Weiner. 1980. Serological relationships among budding prosthecate bacteria. Can. J. Microbiol. 26:209-217.

16. Skerman, V. B. D., V. McGowan, and P. H. A. Sneath (ed.). 1980. Approved lists of bacterial names. Int. J. Syst. Bacteriol. 30:225-420.

17. Stutzer, A., and R. Hartleb. 1898. Untersuchungen über die bei der Bildung von Salpeter beobachteten Mikroorganismen. Abh. Mitt. Landwirtsch. Inst. Koniglichen Univ. Breslau 1:75-100.

18. Wali, T. M., G. R. Hudson, D. A. Danald, and R. M. Weiner. 1980. Timing of swarmer cell cycle morphogenesis and macromolecular synthesis by Hyphomicrobium neptunium in synchronous culture. J. Bacteriol. 144:406-412. 